\title{
Diyarbakır Karacadağ Kilimlerinin Desen ve Motif Özellikleri
}

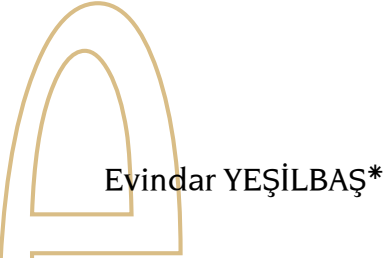

\section{ÖZET}

El sanatlarının folklorik açıdan incelenmesi sonucunda halkların ve kültürlerin, geleneksel süslenme biçimi öğrenilmekte, insanların bedenini ve çevresini güzelleştirme arzusu ile ekonomik kazanç sağlama düşüncesinin varlığı kavranmaktadır.

El sanatı ürünlerinden dokumacılıkta farklı kültürlerle beslenen ve gelişen Anadolu'da kendine özgü özellikler taşıyan çeşitli merkezler mevcuttur. Bilindiği gibi Türk kilimleri hammaddesinden renklerine, içerdiği motiflerden işçiliğine kadar sanat değeri taşıyan örneklere sahiptir. Bu değerli örneklerin üretildiği eski bölgelerden biri de Karacadağ'dır. Bu çalışmada Diyarbakır Karacadağ kilimlerinin tanıtılması, bugünkü koşullarda yapılan üretimin saptanması yer almaktadır. Bildirideki amaç bu kilimlerin desen ve motif özelliklerinin analiz edilmesinden ziyade geleneksel türk sanatlarımızın icra edildiği kilim dokuma merkezlerinden biri olan Karacadağ'ın varlığını ortaya koymak ve yeniden canlandırılması için tartışma ortamı yaratmaktır. Bu bağlamda çalışmada Karacadağ kilimlerinin desen ve motifleri sanat tarihçisi gözüyle incelenmiş, fotoğraflanıp yorumlanmıştır. Ayrıca Karacadağ kilim dokumacılığının devamının sağlanması için gerekli öneriler sunulmuştur.

Anahtar Kelimeler: Diyarbakır, Karacadağ, kilim, desen, motif.
Araştırma Görevlisi- Mardin Artuklu Üniversitesi Edebiyat Fakültesi Sanat Tarihi Bölümü, Mardin, e-posta: evindaryesilbas@gmail.com

\section{Produced in Karacadağ- Diyarbakıı}

\begin{abstract}
As a result of the examination of handcrafts from folkloric point of view, traditional adornment styles of peoples and cultures are learned. This analysis makes it possible to understand the desire of man for beautifying his body and his environment and to conceive the use of this art as a means of economic income.

Among the handcrafts, weaving has many peculiar centers in Anatolia, all of which have developed by nourishing from diverse cultures. As known, Turkish kilims have a worldwide, artistic reputation due to their raw materials, colours, motifs and labour. Karacadağ is one of the production centres where these precious samples are made. Our study does not include the presentation of Diyarbakır - Karacadağ kilims and determination of the production in present conditions. It states that Karacadag is a peculiar center of general Turkish rug-art which is not avaible now and creates discussion environment for revitalization. It is aims to analyse the characteristics of motifs and ornaments of these kilims from art historian's perspectives. In addition, necessary recommendations were suggested to provide continuity of Karacadağ kilims' weaving.

Keywords: Diyarbakır, Karacadă̆, Kilim, pattern, motif.
\end{abstract}

\section{Giriş}

Bir tezgâh üzerinde hazırlanan çözgü ipleri arasından atkı iplerinin çeşitli düzenlerde geçirilmesi, kirkit veya dokuma tarağı ile sıkıştırılması ve ipliklerin birbirine kenetlenmesi sonucu elde edilen ürünlere dokuma denilmektedir. Uygulanan tekniğe ve kulla- 
nılan malzemeye göre dokumanın yüzeyi ve bu yüzeye uygulanabilecek desenler farklılık göstermektedir. Dokumalar kullanılan teknik ve hammaddeye göre değişik isimler almıştır. Dik ve yatay ipler birbirinin arasından geçirilerek kilim, üçüncü bir ip ile desen meydana getirilen; cicim, zili, sumak, teknikleri $^{1}$ ile düz dokumalar meydana getirilmiştir (Foto 1).

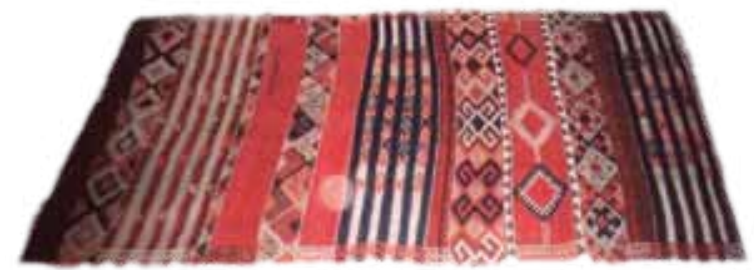

Foto 1. Kuşaklar halinde dokunmuş bir örnek

Düz dokuma çeşitlerinden konumuzu oluşturan kilimler üzerinde biraz daha ayrıntılı tanımlar yapmak gerekmektedir. Dokuma tekniklerinden kilim, motiflerin bulunduğu belirli alanlarda, atkı ipliğinin çözgülerin bir altından, bir üstünden geçerek başka motifin sınırına kadar gitmesi ve buradan geri dönmesidir ${ }^{2}$. Böylece aynı renkteki atkı ipliğinin çözgü ipliklerinin arasından kendi desen alanında gidip gelerek motifleri oluşturmasıdır ${ }^{3}$. Kilim dokunurken iki farklı renkteki atkı ipliklerinin deseni oluşturduktan sonra dönüş noktalarında dikey oluşturdukları deliğe ilik denilmektedir ${ }^{4}$. Bu iliklerin dokuma sırasında değişik şekillerde kapatılması ile değişik kilim türleri ortaya çıkmıştır5.

İnsan hayatında yiyecek, içecek, barınak gibi günlük hayatta kullandıkları araç gereçler de yıllar boyunca araştırılma konusu olmuştur. Düz dokuma tarihine bakıldığında Orta Asya'da yapılan Anavar kazılarında M.Ö. 8000'li yıllara ait düz dokumalarda kullanılan araç gereçlerin ortaya çıkarıldığı görülmektedir ${ }^{6}$. Pazırık kurganlarında en eski halı örneğiyle ${ }^{7}$ beraber düz dokuma parçalarının da ortaya çıkarılmış olması düz dokuma sanatının insan tarihi boyunca var olduğu ve kültür aktarımı yoluyla günümüze kadar devamlılığını sağlayan bir sanat üretimi olduğu söylenebilir.

B. Balpınar Acar, Kilim-Cicim-Zili-Sumak Düz Dokuma Yaygıları, İstanbul 1982, s. 63-68.

2 F. Akpınarlı, "Eşme Kilimleri ile Van Kilimlerinin Genel Özellikleri", II. Uluslar Arası Eşme Kilim Festivali (27 Mayıs 1995), Ankara 1997, s. 53.

3 İ. Ç. Aytaç, "Kirkitli Dokumalarımızın Teknik Özellikleri ve Eski Bir Eşme Kiliminin Desen Analizi", I. Uluslar Arası Eşme Kilim Festivali, Türkiye Kilimciliğinin Üretim ve Pazarlama Sorunları Sempozyumu ( 13-14 Mayıs 1994), Ankara 1995, s. 30.

4 Acar, age., s. 45

5 Acar, age., s. 45

6 G. Atalayer, "Anadolu'da Yaşayan Mekikli El Dokumacılık Tekstil Tasarım ve El Sanatı İlişkisi", Kamu ve Özel Kuruluşlarda Orta Öğretimde, Üniversitelerde El Sanatlarına Yaklaşım ve Sorunları Sempozyumu Bildirileri, Ankara 1994, s. 33.

7 Y. Çoruhlu, Erken Devir Türk Sanat,, İstanbul 2007, s.96-98; O. Aslanapa, Türk Sanatı, İstanbul 1997, s.342.
Anadolu'da bulunan en erken tarihli düz dokuma yaygı örneği, M.Ö. 2300 yıllarına tarihlenen; “kraliçenin örtüsü” adıyla tanınan ancak, bugün nerede olduğu bilinmeyen kilimdir ${ }^{8}$. Truva kazılarında bulunan bu örnek eski resimlerine göre, yıpranmış halde ve açık yeşil, kahverengi, kırmızı renklerle süslenmiş geometrik desenlerle bezeli olduğu söylenilmektedir. 1962 yılında neolitik devre ait olduğu tespit edilen ve şu an Ankara Arkeoloji Müzesinde muhafaza edilen düz dokuma buluntuları da yine Anadolu'da bilinen ilk örneklerdendir ${ }^{9}$. Zaman içerisinde medeniyet seviyesi yükselen Türk toplumlarında da eski bir geçmişe sahip olan dokumacılık, Selçuklularla Anadolu'da izlenerek Osmanlılarla günümüze kadar gelmiştir ${ }^{10}$.

Kilimcilik gerek dokunduğu bölgenin özellikleri ile kültür değerlerini yansıtması ve gerekse dokunduğu bölgeye ekonomik değer katması bakımından önemli geleneksel türk süsleme sanatı ürünlerindendir $^{11}$. Farklı kültürlerle beslenen ve gelişen Anadolu'da kendine özgü özellikler taşıyan çeşitli dokuma merkezleri mevcuttur. Bu merkezlerden Diyarbakır havzasının güneybatısında yükselen Karacadağ, Urfa-Diyarbakır il sınırındaki koyu renkli lavların yığılmasıyla oluşmuş eski bir volkan kütlesidir. Lavları doğu yönünde Dicle Vadisine kadar uzanan dağın eteklerinde kurulan hane sayısı fazla olmayan köylerin yerleştiği alan Karacadağ olarak isimlendirilmektedir. Karacadağ Kilimleri bu bölgede yaşayan halkın gündelik ihtiyaçlarını karşılama amacıyla ürettikleri Geleneksel Türk Sanatı ürünlerindendir. Modern yaşamın el sanatı üretimine olumsuz etkisi Karacadağ kilimlerinde de görülmektedir. 2004 yılında yaptığım alan araştırmasında kilim dokuyan yöre halkının 2008 tarihi itibariyle artık hiçbir suretle dokuma işlerini yapmadıkları saptanmıştır. Yöre halkı ellerindeki kilimleri ticari kaygı ile tarihi Hasan Paşa Hanı'nda bulunan dükkân sahiplerine sattıkları tespit edilmiştir. Çalışmanın amacı bir sanat tarihçisi olarak geleneksel Türk Sanatlarından olan kilim dokumalarından Karacadağ Kilimlerinin ayrıntılı motif ve desen analizlerini ön plana çıkarmaktan ziyade bugün üretimi yapılmayan kilim dokumacılığına dikkat çekerek, yeniden canlandırılması konusunda bir tartışma ortamı yaratıp, neler yapılması gerektiği konusuna değinmektir. Çalışmamızda değerlendirdiğim örnekler 2004-2005 yılları arasında incelediğim kilimlerden seçilmiştir.

8 B. Deniz, Ayvacık (Çanakkale) Yaygıları (Kilim-Cicim-Zili), Ankara 1998, s. 9.

9 Ş. Y. Yağan, Türk El Dokumacılı̆̆ı İstanbul 1973, s. 53.

10 F. Akpinarli, agm., s. 52

11 M. Arlı vd., "Geçmişten Günümüze Eşme Kilimlerinin Renk ve Desen Özellikleri", I. Uluslar Arası Eşme Kilim Festivali, Türkiye Kilimciliğinin Üretim ve Pazarlama Sorunları Sempozyumu (13-14 Mayıs 1994), Ankara 1995, s.137. 
Konu "Karacadağ Kilimlerinde Kullanilan Malzeme ve Teknik" ile "Karacadağ Kilimlerinin Desen ve Motif Özellikleri" başlıklar altında açıklanmaya çalışmıştır. Araştırmanın sonuç bölümünde ise Karacadağ Kilimciliğinin yeniden canlandırılarak eski önemine kavuşması ve devamlılığının sağlanması amacıyla bazı önerilerde bulunulmuştur

\section{Karacadağ Kilimlerinde Kullanılan Malzeme ve Teknik}

Diyarbakır yöresinde yüne dayalı dokumalarda özellikle düz dokuma yaygılarda büyük bir zenginlik ve çeşitlilik söz konusuyken zamanla önemini kaybederek yok olma sürecine girmiştir (Foto 2).

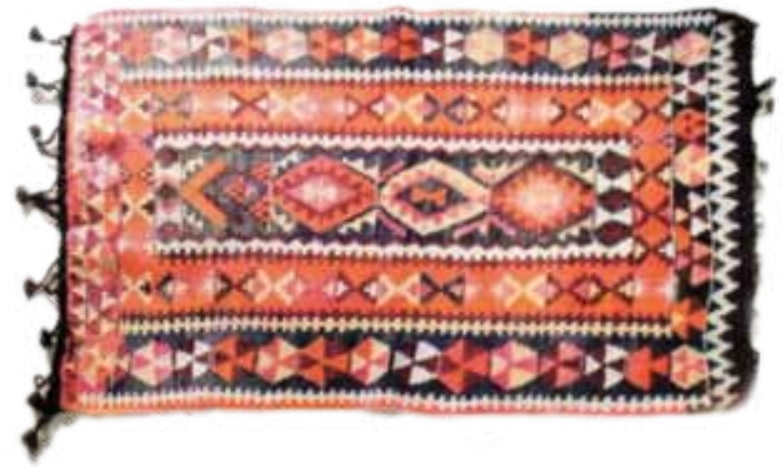

Foto 2. Göbekli dokunan kilimlerden örnek

Karacadağ köylerinde hayvan besleyen aileler ilkbahar ve sonbaharda olmak üzere yılda iki kez hayvandan yün temin edebilmektedirler. Hayvandan kırkılarak alınan yünler öncelikle temizlenme işlemi görüp bunların arasından dokumada kullanılacak ve ipliğe dönüştürülecek yünler ayırt edildikten sonra, yaşlılar tarafından önce yün tarağında taranmakta, koyunun pisliği ve yüne karışan ot dikenleri temizlenmektedir. Taranan yünler "teşi” adı verilen eğirme aletiyle iplik haline getirilmektedir (Foto 3).

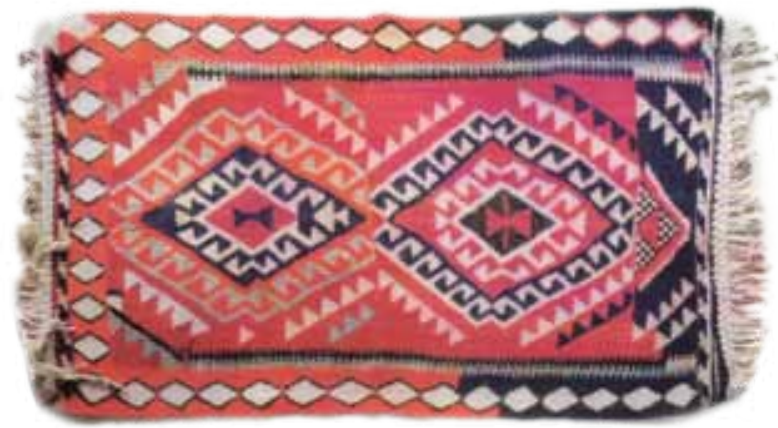

Foto 3. İki göbekli Karacadağ Kilimi (seccade)

Yörede kilim yapımında kullanılan yün iplikleri, eskiden evlerde el eğirmesinde yapılmaktaysa da, uğraşması zor olmasından dolayı fabrikasyon yün ipler de tercih edilmiştir. Yörede, kilim üretiminde kullanılacak olan ipler farklı illerde bulunan iplik fabrikalarından temin edilmektedir.
Elle eğrilerek kullanılan ipler tamamlanmış bir kilime güzellik katan asıl işlemdir. Elle eğrilmiş yünün bükümleri uzunluğuna paralel olarak ayarlanmış liflerle birlikte gevşektir ve kilim yüzeyine pürüzsüzlük vermektedir, bu da kullanılan renkleri güzelleştirerek parlaklık kazandırmaktadır (Foto 4).

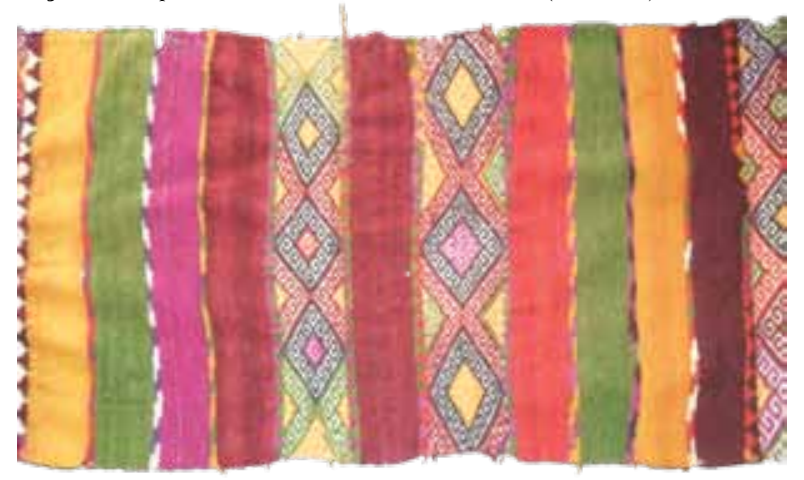

Foto 4. Kilim ve cicim tekniğinin bir arada kullanıldığı bir örnek

Yörede üretilen kilimlerde çoğu zaman çözgüler boyanmadan kullanılmasına rağmen, atkı iplikleri gelepler (çileler) haline getirilerek boyanmaktadır. Boyamada ise yörede bulunan çeşitli bitkilerin yaprak, meyve, kabuk ve köklerinden doğal renkler elde edilmektedir. Eskiden dokumada kullanılan yün iplikleri genellikle evde hazırlanmış boya ile boyanırken son dönemlerde daha ucuz ve zahmetsiz olması nedeniyle sentetik boyaların tercih edildiği yapılan görüşmelerde ileri sürülmüştür. Bazı renkler ise koyunyününün doğal renklerinden elde edilirken fabrikalarda boyalı halde dokumaya hazır iplerin de tercih edilmiş olduğu görülmektedir. Karacadağ kilimlerinde kullanılan renkler veya kullanım tonları kullanım sıklıklarına göre kırmızı veya tonları, sarı veya tonları, beyaz, siyah, mavi, yeşil veya tonları, mor, gri, kahverengi veya tonlarıdır. Teknik olarak çoğunlukla kilim, cicim veya iki tekniğin de bir arada kullanıldığı örnekler dikkati çeker (Foto 5).

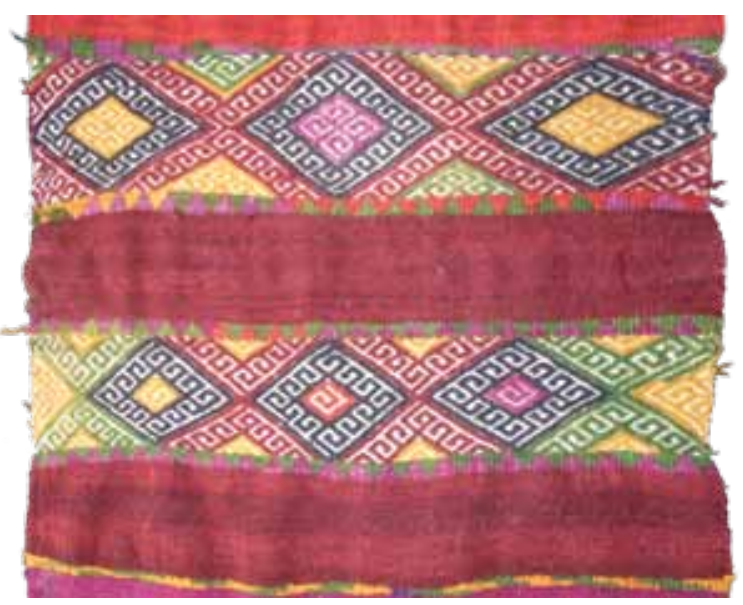

Foto 5. Kilimden detay 
Karacadă̆ Kilimlerinin dokunmasında daha önceleri yer tezgâhları kullanılırken son yıllarda Anadolu'nun çeşitli dokuma merkezlerinde karşılaştığımız tezgâh tipi olan "1star" tezgâhların yanı sıra modern tezgâhlar da kullanılmıştır ${ }^{12}$.

\section{Karacadağ Kilimlerinin Desen ve Motif Özellikleri}

Diyarbakır Karacadağ kilimleri kullanıldıkları yere göre; taban kilimi, yolluk kilimi, seccade, divan kilimi, duvar kilimi, yastık kilimi, minder kilimi olarak ayrilmaktadirlar.

Karacadağ Kilimleri, geometrik, stilize hayvan ve bitki motifleri ile süslenmiştir. Düz dokumalarda genellikle geometrik şekillerin bir araya getirildiği kompozisyonlar ya da geometrik tarza uydurulmuş stilize edilmiş hayvan ve bitki motiflerinden oluşturulmuş kompozisyonlar dikkati çeker. Düz dokuma tekniğinde desen oluşturma yapılan bir desenin ardından yeni bir desen işleme gibi kolaylıklar sağladığından kompozisyon oluşumları bir anlamda zorunluluk sonucu ortaya çıkmaktadır. Teknik olarak yatay iplik sıralarıyla dokunan yaygıların nakışlarının geometrik veya geometrize edilmiş biçimlerden oluşması kaçınılmaz bir olaydır ${ }^{13}$.

Kilim dokumada desenler genellikle dokuyucudan öğrenmeye çalışanlara ezberletilerek devamlılık sağlar. Dokuyucuların bazen daha önce kullanılan desenlerini kendilerine örnek aldıkları da görülür. Deseni oluşturan her motif zenginliği ve çeşitliliği ile tarih boyunca toplumların gelenek, görenek, zevk, anlayış ve inançlarının bir ifadesi olmuştur ${ }^{14}$.

Karacadağ kilimlerinin birçoğunda kenar su çerçevesi kullanılırken bazılarında bu durum söz konusu değildir. Su bordürü olarak en çok zikzaklar, meandırlar içinde geometrik şekilleri olan altıgenler, devetabanı, küçük kurbağa gibi motifler kullanılmaktadir (Foto 6).

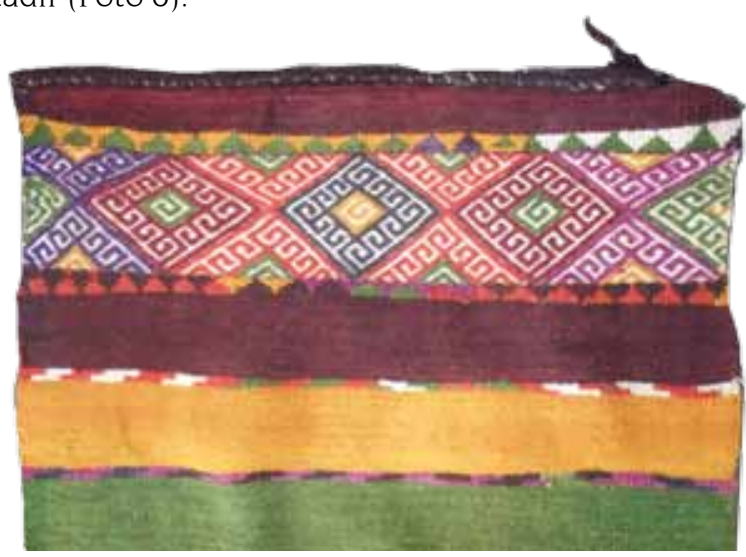

Foto 6. Kilimin saçak kısmındaki desenden detay

12 B. Acar, age., s. 41

13 S. Mülayim, "Plastik Sanatlarda Anlatım Biçimleri ve Üslup", Arkeoloji- Sanat, s. 110

14 F. Akpinarli, agm., s. 62
Kilimlerde kullanım alanına göre tek parça veya iki parçadan (iki şak) yapılarak birleştirildiği örnekler de bulunmaktadır (Foto 9). Kilimlerin çoğu orta kısımda üç göbekli, beş göbekli kompozisyonlara sahipken sadece uç ve orta kısmında motiflere sahip kilimler de dikkati çekmektedir (Foto 7, Foto 8). Kilim örneklerinde karşılaştı̆̆ımız bir diğer özellik ise göbekli işlemelerin dışında bir düzen içerisinde sıralar halinde kuşak kuşak kompozisyonların da oluşturulduğudur. Kilimlerde stilize edilen her motife sembolik bir ifade yüklenmiştir ${ }^{15}$. Yörede kilimi dokuyan kadın duygularını, düşüncelerini, sevinçlerini, üzüntülerini, istek ve arzularını, endişe ve korkularını motifler üzerinden dokuduğu kilime yansıtmayı, anlatmayı başarmıştır.

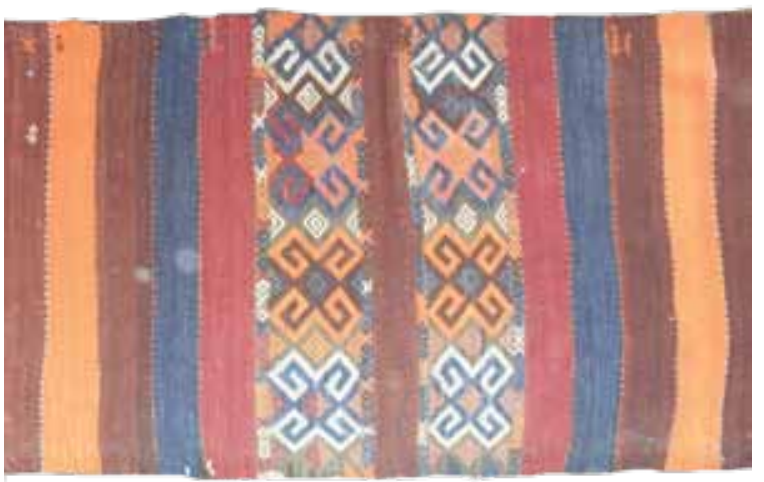

Foto 7. Orta ve uç kısımlarında desen oluşturulmuş kilimlerden örnek

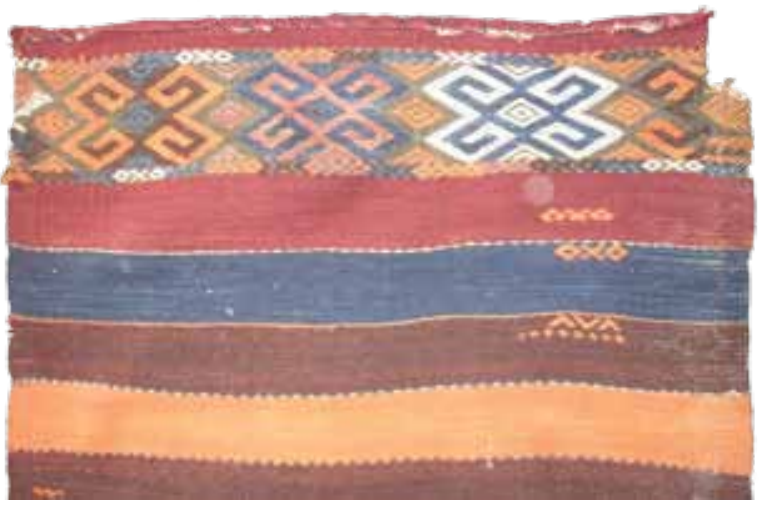

Foto 8. Kilimden detay

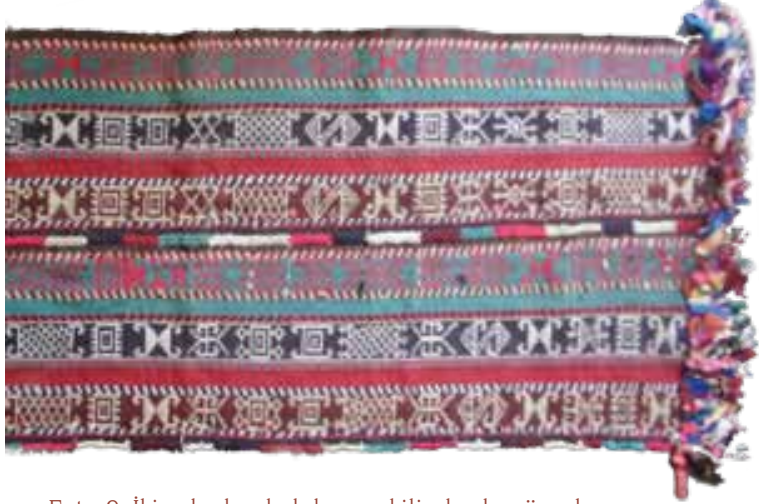

Foto 9. İki şak olarak dokunan kilimlerden örnek

15 Aytaç, agm., s. 36. 
Kilimlerin dokunuşunda kullanılan motiflerin tamamını burada açıklamak mümkün olamayacağından aşağıda sadece sıklıkla karşılaştı ̆̆ımız motiflerin bazılarına değinilmiştir.

Elibelinde (Eliböğründe): Yöredeki dokuma örneklerinde oldukça fazla uygulanmış bir motiftir. Analık ve doğurganlıkla beraber uğur, bereket, kısmet, mutluluk ve neşeyi sembolize eder. Bilindiği gibi, insanlığın yaradılışından bu yana "ana" kavramı, hayatın ilk nüvelerinin oluştuğu ve geliştiği kaynağı ifade etmektedir. Bundan dolayı toprak ve deniz, ana olma durumu ile özdeşleştirilmiştir. Bu görüş tüm canlıların su ve topraktan oluştuğu varsayımı ile de örtüşmektedir. Anadolu inançlarında yaşam ve ölüm ayrılmaz bir bütündür ${ }^{16}$ (Şekil 1). Bu motif kilimlerin merkez noktası sayılan kilimin ortasında, kenarlarında bordür olarak ve uç kısımlarda kuşak halinde dokunmuştur.

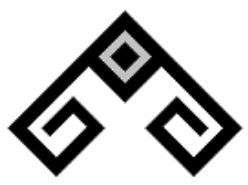

Şekil 1. Elibelinde Motifi

Koçboynuzu: Bereket, kahramanlık, güç ve erkeklik sembolü olan koçboynuzu motifi, Anadolu kültüründe ana tanrıçadan sonra ya da onunla birlikte kullanılan bir motiftir. Erkekle özdeşleştirilmiş boynuz sembolü, insanlık tarihinde güç, kuvvet timsali olarak kullanılmaktadır ${ }^{17}$ ( Şekil 2).

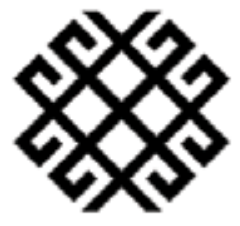

Şekil 2. Koçboynuzu motifi

Kurt Ağzı, Kurt İzi (Yan Ala): Anadolu dokumalarında koruma amaçlı kullanılan bu motif yöre dokumalarında yaygın olarak kullanılmıştır (Şekil 3).

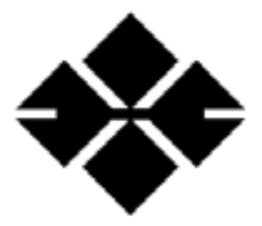

Şekil 3. Kurtağzı Motifi

Göz (Dört Göz, Dana Gözü): Dokunan kilimlerde geometrik özellik arz eden ve yöre halkı tarafından farkIı isimlerle anılan göz motifi çok sıklıkla kullanılmıştır.

Pıtrak: Pıtrak motifi, bereketli olmaları için un çuvallarında, tandır örtülerinde, ekmek üstüne kapanan cicim dokumalarında sıkça kullanılmıştır (Şekil 4).

\footnotetext{
16 M. Erbek, Çatal Höyükten Günümüze Anadolu Motifleri, Ankara 2002, S. 12 .

17 M. Erbek, age., s.30.
}

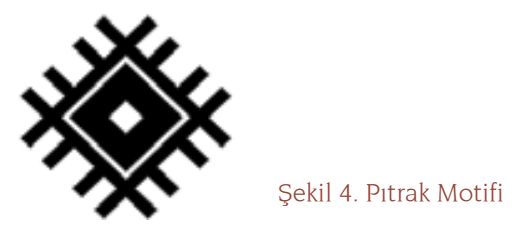

Muska (Nuska, Nuksa, Noksa), Nazarlık: Bazı insanların cisimlere ve varlıklara bakmak suretiyle maddi ve manevi tesir meydana getirmesi halini ifade eden nazar, insan bakışlardan fırlayan çarpıcı ve öldürücü bir kuvvet olarak da tanımlanmaktadır ${ }^{18}$. Böylesi kötü ve negatif etkilerden korunmak için insanlar muska ve çeşitli nazarlıklar kullanmışlardır. Bunları dokudukları dokumalara da motif olarak yansıtmışlardır (Şekil 5).

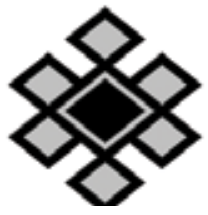

Şekil 5. Muska Motifi (E. Subaşı'ndan)

Tarak: El motifine benzemekle beraber kenarlarda su olarak ve dokumayı bölümlere ayırmakta kullanılmıştır (Şekil 6). Karacadağ kilimlerinde şerit halinde oluşturulan kompozisyonlarda başka bir motifle dönüşümlü dokunan bir motiftir.

\section{IIIIII IIIII \\ Şekil 6. Tarak Motifi}

El, Parmak: Dokumaların kenarlarındaki suların oluşturulmasında ve bordürlerin sınırlarında yaygın bir şekilde kullanılmıştır. Bereket, bolluk ve yaşamı koruyan motiflerdendir.

Yılan (Ejder) Motifi: Astrolojiyi temsil etmekle beraber, Orta Asya'da dünyanın dönmesini sağlayan, gece ve gündüzün meydana gelmesini temin eden, iyilik, kötülük, sağlık, kahramanlık sembolü olarak kullanılmaktaydı. Dokumalarda dünyayı, kötülük, göz değmesi, nazar gibi duygulardan korunmak üzere işlenmiş bir sembol olarak kullanıldığı düşünülmektedir ${ }^{19}$ (Şekil 7).

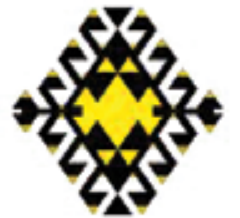

Şekil 7. Yilan (Ejder)motifi

Kilimlerde sonsuzluğun ifadesi ${ }^{20}$ olan hayat ağacl, kötülüklerin sembolü${ }^{21}$ olan yengeç ve akrep,

18 M. Erbek, age., s. 120

19 B. Deniz, "Anadolu Türk Dokumalarında Ejder Motifi", Türk Soylu Halkların Halı, Kilim ve Cicim Sanatı Uluslar Arası Bilgi Söleni Bildirileri, Kayseri, 1996, s. 102 - 108.

20 R. Karahan, "Van Kilimleri", Kültür ve Sanat (Van Özel Sayısı), S.32, Ankara 1996, s.44-46.

21 R. Karahan, agm., s.45. 
balık motifleri stilize edilerek kullanılan diğer motiflerdir.

Bunların dışında geometrik tarzda çok sayıda motif kilimlerin desenlerini oluşturmada kullanılmıştır. Motiflerin kendi içinde sınırlandırılabildiği gibi başlangıcı ve bitişi belli olmayan sonsuzluk etkisi çağrıştıran uygulamalar da görülmektedir. Sonsuzluğu vurgulayan yarım bırakılmış ucu açık motif ve kompozisyonların kullanılması bir anlamda kişinin kutsalla olan bağını desen ve motifler üzerinden kurduğunu gösterir. Geometrik bezeme olarak; baklava biçimi, suyolu (sığır sidiği, dikme, akıtma, deve hörgücü), bereket (bereket çaprazı), altıgen, dikdörtgen, eşkenar dörtgen, aşk birleşim, çengel, yıldız biçimleri görülmektedir. Kullanılan motifler Anadolu'da diğer yörelerde dokunan kilimlerde karşılaştığımız motiflerden pek farklı olmadan vurgulanmak istenen duygu ve düşüncelerin yansımasıdır.

\section{Sonuç}

Eskiden beri insanoğlunun yaşantısında önemli bir yeri olan düz dokumalar sağlıklı malzemelerden yapılmış, kullanışlı, estetik ve kültürümüzün bir parçası olduğu için yöre yaşantısında önemli bir yer edinmiştir. Ancak son yıllarda dokuma merkezlerinin arz ve taleplerin azalmasına bağlı olarak önemini yitirdiğini görmekteyiz. Dokumada devamlılığı sağlayan ve üretimde canlılığını yitirmeden devam eden merkezlerde ise doğal yolla elde edilen malzemelerin yerine fabrikasyon malzemelerin tercihi kalitenin düşmesine sebep olmuştur.

Diyarbakır Karacadağ Kilimlerinde de önceleri koyunyününden elde edilen iplerin kullanıldığı ancak son yıllarda ise farklı illerden temin edilen iplerin dokumada tercih edildiği görülür. Kullanılan renklerin daha çok kırmızı ve tonları, mavi, yeşil ve tonları, siyah, beyaz, kahverengi ve tonları olduğu tespit edilmiştir. Kilim dokumada desen ve motiflerin stilize olarak bitki ve hayvan şekillerinden tercih edilmesinin yanı sıra geometrik şekillerin de ön planda olduğu dikkati çeker. Sıklıkla karşılaştığımız motifler ise elibelinde, koçboynuzu, kurtağzı, pıtrak, muska, göz, baklava biçimi, suyolu (sığır sidiği, dikme, akıtma, deve hörgücü), bereket (bereket çaprazı), altıgen, dikdörtgen, eşkenar dörtgen, aşk birleşim, yıldız biçimleridir. Göbekli kompozisyonların yanı sıra kilim örneklerinde düz renkte şeritler arasına desenli şeritlerin dokunarak kompoze edildiği örnekler de mevcuttur.

Türk Süsleme sanatları açısından geleneksel kilim dokumacılığının geliştirilmesi hem turistik değerlerin canlandırılması hem de kilim ticaretinde satışların arttırılması açısından kaçınılmaz bir durumdur.

2008 yılına kadar Karacadağ kilim dokuma atölyeleri mevcutken bugün arz ve talep eksikliği ve modern yaşam getirisi fabrikasyon halı ve kilimlerin tercih edilmesi kilimciliğin değer kaybetmesine sebep olmakla beraber dokumayı yapan kişilerin de bu işle uğraşmaktan vazgeçmesine neden olmuştur. Geleneklerimizin özelliklerini yansıtan renk ve motiflerle günümüzün beğeni ve ihtiyaçlarını karşılayacağını düşün- düğüm Karacadağ Kilimlerinin tanıtılıp üretimde devamlılığını sağlamak amacıyla birkaç öneri sunulabilir. Önerilerden ilki sosyal destekli ( SODES) hazırlanacak proje ile eskiden kilim dokuyan kadınların tespit edilerek bir araya getirilmesi ve Karacadağ Kilimciliğinin yeniden eski canlılığıyla üretime geçirilmesi sağlanabilir. Bu kapsamda daha sonra Halk Eğitim Merkezi, Sosyal Güvenlik Kurumu ve Turizm İşletmeleri tarafından dokuma atölyeleri kurulması önerilebilir. Dokuyucuların dokuma alanındaki bilgi, becerilerini yeni kuşak yöre gençlerine öğreterek kaybolmakta olan dokumacılığın önüne geçerek bu durumun ekonomiye katkı sağlayacak şekilde projelendirilebileceği kanaatindeyim. Bunun sonucunda halkı kendi ihtiyaçlarını karşılamak ve çeyiz hazırlamanın yanı sıra ticaret amacıyla siparişlerin karşılanmasına yönelik kilim dokumasına sevk etmiş oluruz.

Karacadağ Kilim üretiminin yeniden canlandırılması için sunulabilecek bir diğer öneri ise kilimlerde sıklıkla kullanılan motif ve kompozisyonların uzman kişiler tarafından ayrıntılı bir şekilde incelenip desenleri çizildikten sonra kültür turizmi bağlamında küçük el sanatları ürünlerine (para keseleri, çantalar, küçük yastıklar, vb.) yansıtılmasıdır. Bu şekilde üretimini sağlayamadığımız geleneksel değerlerimizin motif ve kompozisyonları modern yaşam potasında eritilerek veya yeni bir fonksiyon kazandırılarak en azından sonraki kuşaklara aktarma imkânına sahip oluruz.

\section{Kaynaklar}

Acar- Balpınar, Belkıs (1982), Kilim-Cicim-Zili-Sumak Düz Dokuma Yaygıları, İstanbul.

Akpınarlı, Feriha (1997), “Eşme Kilimleri ile Van Kilimlerinin Genel Özellikleri", II. Uluslar Arası Eşme Kilim Festivali (27 Mayıs 1995), Ankara, s. 51-74.

Arlı, Mustafa vd. (1995), "Geçmişten Günümüze Eşme Kilimlerinin Renk ve Desen Özellikleri", I. Uluslar Arası Eşme Kilim Festivali, Türkiye Kilimciliğinin Üretim ve Pazarlama Sorunları Sempozyumu (13-14 Mayıs 1994), Ankara, s. 137-147.

Aslanapa, Oktay (1997), Türk Sanatı, İstanbul.

Atalayer, Güney (1994), “Anadolu'da Yaşayan Mekikli El Dokumacılık Tekstil Tasarım ve El Sanatı İlişkisi”, Kamu ve Özel Kuruluşlarda Orta Öğretimde, Üniversitelerde El Sanatlarına Yaklaşım ve Sorunları Sempozyumu Bildirileri, Ankara, s. 33-41.

Aytaç, İ. Çetin (1995), “Kirkitli Dokumalarımızın Teknik Özellikleri ve Eski Bir Eşme Kiliminin Desen Analizi", I. Uluslar Arası Eşme Kilim Festivali, Türkiye Kilimciliğinin Üretim ve Pazarlama Sorunları Sempozyumu (13-14 Mayıs 1994), Ankara, S. 30-39.

Çoruhlu, Yaşar (2007), Erken Devir Türk Sanatı, İstanbul.

Deniz, Bekir (1996), "Anadolu Türk Dokumalarında Ejder Motifi", Türk Soylu Halkların Halı, Kilim ve Cicim Sanatı Uluslar Arası Bilgi Şöleni Bildirileri, Kayseri, s. 102 - 108.

Deniz, Bekir (1998), Ayvacık (Çanakkale) Yaygıları (Kilim-CicimZili), Ankara.

Erbek, Mine (2002), Çatal Höyükten Günümüze Anadolu Motifleri, Ankara.

Karahan, Recai (1996), "Van Kilimleri”, Kültür ve Sanat (Van Özel Sayısı), S. 32, Ankara, s.44-46.

Yağan, Şahin Yüksel (1973), Türk El Dokumactlı̆̆, İstanbul. 